\title{
BIOSKOP KELILING PERANANNYA DALAM MEMASYARAKATKAN FILM NASIONAL DARI MASA KE MASA
}

\author{
THE CINEMA MOBILE: \\ THE ROLE IN POPULARIZING NATIONAL MOVIES THROUGH THE TIME
}

\author{
Heru Erwantoro \\ Balai Pelestarian Nilai Budaya Bandung \\ Jln. Cinambo 136 Ujungberung Bandung \\ e-mail: herubpnb@yahoo.com
}

\begin{abstract}
Abstrak
Film masuk ke Hindia Belanda untuk pertama kalinya pada tanggal 5 Desember 1900 dalam format bioskop keliling. Bioskop keliling ternyata mampu eksis dari masa ke masa karena ada faktor yang mendukung keberadaannya. Melalui pendekatan historis, penelitian ini mencoba untuk menelusuri perjalanan bioskop keliling dari masa ke masa dan peranannya dalam perfilman nasional. Penelitian ini memiliki arti yang signifikan bagi perkembangan perfilman nasional. Dari penelitian ini terungkap bahwa: (1) eksistensi bioskop keliling ditentukan oleh motif ekonomi dan motif politik. Secara ekonomis, bioskop keliling menjual jasa pemutaran film langsung ke konsumennya secara massal dan murah, namun tetap menjanjikan keuntungan secara finansial. Motif politik menjadikan film sebagai instrumen politik, namun demikian motif politik ini membuat eksistensi bioskop keliling semakin kokoh; (2) bioskop keliling merupakan mesin peredaran film nasional yang sangat efektif di dalam memasyarakatkan film nasional ke tengahtengah masyarakat. Melalui bioskop keliling mimpi film nasional menjadi tuan rumah di negeri sendiri secara realistik dapat terwujud. Anggapan yang selama ini dipahami oleh kalangan perfilman bahwa menjadi tuan rumah di negeri sendiri hanya dapat dicapai dengan cara menguasai bioskop yang permanen, mewah dan yang berada di kota-kota berakibat mengubur potensi besar yang dimiliki bioskop keliling.
\end{abstract}

Kata kunci: bioskop keliling, film nasional.

\begin{abstract}
The first time of movie come to the Dutch East Indie in December $5^{\text {th }} 1990$ on cinema circumference. Cinema circumference exists from time to time since there are factors that support the existence. Through historical approach, the research tries to browse the cinema trip around from time to time and its role in national film. The research has a significant means in the developing of national film. From the result, it can be seen that (1) the existences of cinema circumference decided by the economic motif and political motif. Economically, cinema circumference sells the screening services directly to consumers in bulk and cheap, but still promising benefit financially. Political motives make the film as a political instrument; however it makes the existence of a political motive theater sturdy. (2) Cinema circumference is the main power of national film which is very effective in promoting national film to society. Through national movie theaters, the dream to be a host on their own country can realistically be realized. The assumption, that hosts in their own country can only be achieved by means of holding a
\end{abstract}


permanent cinema master, luxurious, and located in cities is burying large potential of circumference cinema.

Keywords: mobile cinema, national movie

\section{A. PEN DA HULUAN}

Bioskop sebagai ujung mata rantai perfilman merupakan tempat bertemunya konsumen (penonton) dengan komoditas jasa yang bernama film. Pada titik inilah terjadi tarik-menarik antara kepentingan mengusung perfilman nasional yang produksinya tidak memadai dengan jumlah bioskop yang ada serta kepentingan menjaga kelangsungan bisnis bioskop dengan menjual film impor. Hal itu menjadikan kondisi perbioskopan bersifat fluktuatif (Irawanto et al., 2004: 97).

Padahal perfilman di Indonesia tidak hanya menggunakan bioskop dalam peredaran film, tetapi juga menggunakan apa yang disebut dengan bioskop keliling atau yang sering juga disebut dengan istilah layar tancap. Bila bioskop saja mengalami fluktuatif, apalagi dengan layar tancap.

Pada dasarnya yang dinamakan bioskop keliling adalah peredaran film secara sederhana melalui cara yang lebih praktis dan bersifat mobil karena dapat berpindah dari satu tempat ke tempat lain. Oleh karenanya, bioskop keliling mempunyai keunggulan, yaitu kemampuan menjangkau desa-desa yang tidak memiliki bioskop.

Secara teknis bioskop keliling hanya berupa perangkat keras yang terdiri atas sebuah proyektor, layar berukuran (3 X $7 \mathrm{~m}-4$ X $8 \mathrm{~m}$ ), konstruksi untuk mendirikan layar (tiang bambu, besi knockdown), sound system (amply, speaker, tapedeck), player, copy film, tenda yang dikemas dalam alat transportasi yang dioperasikan oleh 1 orang supir dengan 2 orang crew operator diesel.

Dari catatan sejarah, bioskop keliling ini sudah mulai dikenal sejak zaman Hindia Belanda. Namun pada awal kemerdekaan bioskop keliling kurang mendapat perhatian dari kalangan perfilman nasional karena dianggap sebagai pengamen belaka. Dalam perkembangannya, para pengusaha bioskop keliling membentuk organisasi dengan membentuk Yayasan Persatuan Bioskop Keliling Indonesia (PERBIKI) pada bulan Februari 1978. Organisasi ini kemudian berubah menjadi Persatuan Perusahaan Film Keliling Indonesia (PERFIKI) pada bulan Desember 1991.

Keadaan dunia perfilman di Indonesia pada awal abad XXI ini masih diwarnai oleh berbagai persoalan yang merupakan warisan abad sebelumnya. Salah satu persoalan itu adalah menyangkut distribusi film. Masalah distribusi film di Indonesia begitu kompleks. Berbicara tentang distribusi film tentunya merujuk pada realitas bisnis yang meliputi pengadaan film impor, distribusi atau peredaran film, dan eksibisinya di bioskop yang dalam praktik bisnisnya mengacu pada konsep integrasi vertikal (Irawanto, et al. 2004: 96). Dalam distribusi perfilman di Indonesia terdapat kekuatan tunggal yang mempunyai hak sebagai pengimpor film sekaligus koordinator film. Kekuatan yang sama ini juga mempunyai pengaruh menentukan jadwal pemutaran film di bioskop yang cenderung mengutamakan film impor (Junaedi, 1994 dalam Irawanto, et al. 2004: 96).

Dari uraian di atas timbul masalah pokok penelitian, yaitu "Bagaimanakah peran Bioskop Keliling dalam peredaran film nasional?" Adapun tujuan penelitian ini adalah untuk mengetahui peran bioskop keliling dalam peredaran film nasional dengan cara menelusuri sejarahnya.

\section{A. METO DE PEN ELITIA N}

Dunia perfilman Indonesia mengalami kemelut yang berkepanjangan, tetapi upaya-upaya yang dilakukan selama ini kurang memerhatikan faktor sejarahnya. Kelalaian berpikir historis 
inilah yang nampaknya mendorong kita untuk cenderung membuat rencana "melompat jauh ke depan" tanpa secukupnya menyadari realitas sekarang (Erwantoro, 1994: 5-6). Dalam hal ini sejarawan mengingatkan untuk mau melihat sejarah.

Setelah melihat masa lampau, kata sejarawan Pilipina, JRM Taylor, akan nampak bahwa pengertian dan pemahaman kita tentang masa kini sebenarnya miskin. Berbagai aspek sejarah tersembunyi dari pandangan kita. Ini bisa bersumber dari atau dipertajam oleh proses misedukasi. Oleh karena tidak mempunyai akses yang cukup terhadap fakta atau kebenaran sejarah, maka sense of histories makin menipis (Rahardjo dalam Prisma, 8 Agustus 1983, hal: 2).

Dalam konstelasi inilah penelitian sejarah dapat membantu agar kita tidak kehilangan apresiasi terhadap hubungan kita dengan masa lampau yang sesungguhnya mengandung banyak arti untuk menjelaskan berbagai persoalan masa kini.

Adapun penelitian sejarah secara umum menggunakan metode sejarah yang terbagi dalam empat tahapan, yaitu: heuristik, kritik, interpretasi, dan historiografi.

Tahap heuristik, yaitu pencarian dan pengumpulan sumber tertulis, dilakukan studi pustaka di beberapa perpustakaan yang terdapat di Jakarta (Perpustakaan Nasional, Perpustakaan Umum Daerah DKI Jakarta, dan Perpustakaan Sinematek Indonesia) dan Bandung (Perpustakaan UPI dan Perpustakaan UNPAD).

Terhadap sumber yang diperoleh kemudian dilakukan kritik eksternal dan internal untuk menilai otentisitas sumber dan kredibilitas informasinya. Sumbersumber itu kemudian diolah untuk memperoleh data yang diperlukan.

Selanjutnya terhadap data yang sudah diseleksi dilakukan interpretasi, sehingga diperoleh fakta. Tahap terakhir merangkaikan fakta berdasarkan hubungkaitnya secara sistematis dan kronologis, sehingga menjadi kisah sejarah berupa rekonstruksi peristiwa yang diteliti.

\section{B. HASIL DAN BAHASAN}

1. Masuknya Film ke Indonesia

Pada akhir abad ke-19 banyak keajaiban terjadi di dunia dengan adanya berbagai penemuan, seperti penemuan fotografi oleh Louis Daquere (Perancis) pada tahun 1839, phonograph yang bisa merekam suara oleh Thomas Alva Edison pada tahun 1887, Radio oleh C. Marconi pada tahun 1895, dan film oleh Louis dan Auguste Lumiere (Perancis) pada tahun yang sama (Jauhari, 1992: 2). Keajaiban yang bagaikan kekuatan sihir menjelmakan segala sesuatu yang tadinya tidak masuk akal, membuat dunia terasa makin sempit dan waktu berjalan semakin cepat.

Penemuan di belahan dunia yang lain menyebar ke bagian dunia yang lainnya dengan cepat. Begitu juga dengan film. Sejak pertunjukan pertamanya yang berlangsung di Grand Café Boulevard des Capucines Paris (Perancis) pada tahun 1895, kemudian film menyebar ke berbagai negara, yaitu ke Inggris (London) pada bulan Februari 1896, Uni Sovyet (St. Petersburg) pada bulan Mei 1896, Jepang pada tahun 1896 - 1897, Korea pada tahun 1903, dan di Italia pada tahun 1905. Di Indonesia (Hindia Belanda) pertunjukan film untuk pertama kalinya berlangsung pada tanggal 5 Desember 1900, berarti 5 tahun sesudah bioskop pertama di dunia di Paris memulai pertunjukan film (Ardan, 1984: 1).

Di Batavia pada tanggal 30 November 1900 sebuah iklan di surat kabar "Bintang Betawi" menyatakan:

"De Nederlandsch Bioscope
Maatschappij (Matschappij Gambar
Idoep) memberi tahoe bahoewa lagi
sedikit hari ija nanti kasi lihat tontonan
amat bagoes jaitoe gambar gambar
idoep dari banyak hal jang belon lama


telah kejadian di Europa dan di Afrika Selatan.

Ini tontonan nanti dikasih lihat didalam roemah disebelahnja Fabriek kereta dari Maatschappij Fuchs di Tanah Abang. Hari moelainja tontonan ini nanti dikasih taoe dilaen tempo".

Penduduk di tanah jajahan menunggu-nunggu realisasi dari kabar ini. Warung-warung kopi, pasar, dan tempattempat berkumpul ramai membicarakan bayangan keajaiban ini. Orang mencoba membayangkan bagaimana kiranya benda yang akan dipertontonkan itu, yang konon mampu memperlihatkan dengan nyata segala kejadian yang belum lama terjadi di Eropa dan Afrika Selatan. Tidak sedikit pula orang yang mencoba membandingkan tontonan yang akan datang itu dengan yang selama ini telah dipertunjukkan oleh Tuan Talbot di Lapangan Pasar Gambir. Umumnya, orang kemudian sampai pada kesimpulan, tontonan yang akan dipertunjukkan nanti, pasti lebih hebat dari sekadar rangkaian gambar yang disajikan Tuan Talbot (Jauhari, 1992: 2).

Orang menanti-nanti, desas desus menyebar apalagi ketika Bintang Betawi melengkapi iklannya pada tanggal 4 Desember 1900 yang berbunyi:

\section{"Besok hari Rebo 5 Desember 1900 PERTOENDJOEKAN BESAR JANG PERTAMA didalem satoe roemah di Tanah Abang, Kebondjae (Menage) moelain poekoel toedjoe malem, Harga Tempat klas Satoe f2, klas Doewa fl, klas Tiga f0,50" (Ardan, 1984: $1)$.}

Film yang dipertunjukkan ternyata adalah film dokumenter, seperti disebut di dalam iklannya:
"Masoeknja
Sribaginda Maharatoe Olanda bersama-sama jang moelija Hetog Hendrik ke dalam kota Den hag, roepa-roepa hal jang telah terjadi didalam

peperangan di Transvaal. Lebih jauh ditontonkan djoega gambarnja barang-barang matjem baroe jang telah ada didalem Tentoonstelling di kota Parijs, gambar-gambar berwarna jang terdapat dari fotografie jang dari sebab amat adjaibnja soeda ditonton pada saban sore oleh riboean orang di komidie Salle de Fetes di kota Parijs" (Ardan, 1984: 2).

Kegemparan yang ditimbulkan barang ajaib bernama gambar hidup itu, tanpa diduga mereda dengan cepat. Orang ramai membicarakan tontonan yang dipertunjukkan oleh Tuan Scharwz di sebuah rumah yang difungsigandakan tersebut, tidak jauh berbeda dengan gambar hidup yang sering dipertunjukkan Tuan Talbot di Pasar Gambir di muka Stasiun Kota dan di Lokasari Manggabesar. Bedanya, Tuan Scharwz menyajikan pertunjukan di dalam sebuah rumah di tanah Abang Kebonjae (kelak bernama The Royal Bioscope), sedangkan Tuan Talbot dan rekan-rekannya selalu mempertunjukan film di dalam bangunan berdinding bambu (bilik) beratap seng, yang didirikan di lapangan terbuka dan selalu berpindah-pindah (Jauhari, 1992: 5).

Gambar yang disajikan juga belum dapat dinikmati secara sempurna. Selain sering bergetar dan goyang sehingga membuat mata lelah dan sakit, juga pertunjukan itu hanya berisi gambar yang tidak mengandung cerita yang membuat orang cepat merasa bosan. Faktor harga juga dirasakan terlalu mahal, akibatnya, bioskop pertama di Hindia Belanda dengan cepat kekurangan penonton (Jauhari, 1992: 5). demikian itu, pengusaha bioskop melakukan upaya merangsang datangnya penonton dengan menurunkan harga karcis, seperti dinyatakan pada iklan tanggal 31 Desember 1900, bahwa: 
"Moelain 1 Djanoeari 1901 bajaranja dikoerangin. Kelas Satoe f1,25 (semula f2), Kelas Doewa f0,75 (tadinja f1) dan Kelas Tiga f 0,25 (sebelumnja f 0,50)". Di samping pengumuman itu, terdapat pula tambahan tentang pertunjukan khusus seminggu sekali, saban (tiap) hari Rebo, yaitu "Pertoenjoekan boeat anak-anak", pembajaran boeat satu anak dan penghantarnja f 0,50 " (Ardan, 1984: 2).

Dengan adanya penurunan harga karcis itu, animo terhadap bioskop agak meningkat. Orang umumnya datang untuk menyaksikan benda ajaib yang diiklankan dan menjadi buah bibir itu. Selain itu, nonton bioskop termasuk bergengsi, terutama karena jenis hiburan ini baru dan menjadi konsumsi orang berduit. Dengan nonton bioskop, para inlander merasa naik harga dirinya karena bisa duduk bersama dengan para sinyo dan noni-noni yang pada waktu itu mempunyai kedudukan yang paling tinggi dalam strata sosial masyarakat Hindia Belanda (Jauhari, 1992: 6).

\section{Bioskop Keliling}

Bila kita bertitik tolak pada pengertian film sebagai Moving images on the screen, dapatlah dikatakan bahwa film sudah berada di Hindia Belanda sejak ditayangkannya "gambar idoep" oleh Scharwz pada tahun 1900. Meskipun tampak sangat bersahaja, yaitu berupa rangkaian gambar bergerak tak bersuara, sering bergetar dan goyang sehingga menyebabkan rasa sakit di mata tetapi tetap menarik perhatian orang. Selain merupakan hasil dari kemajuan teknologi, film menurut Roy Paul Madsen (1973: 5-6) mempunyai kelebihan. Film yang titik sentralnya pada gambar visual sangat berpengaruh pada manusia. Manusia melihat dengan mata, yang mempunyai kaitan langsung pada otak dan merupakan sarana utama bagi orang, yang secara fisik normal, untuk belajar tentang dan berhubungan dengan lingkungannya. Penglihatan menyediakan komunikasi secara langsung pada pikiran, dan kesankesan dengan tidak perlu diterjemahkan agar dapat dimengerti.

Di Indonesia, kelebihan media film sebagai mana diuraikan di atas untuk pertama kalinya dipakai sebagai media propaganda oleh pemerintah Pendudukan Jepang. Melihat pentingnya arti film sebagai media propaganda, sejak awal pendudukannya pemerintah militer Jepang telah melakukan kontrol sepenuhnya atas dunia perfilman. Staf propaganda yang menyertai operasi militer, menyita seluruh perusahaan perfilman. Untuk melaksanakan kebijakan di bidang perfilman, Sendenbu pada bulan Oktober 1942 membentuk Jawa Eiga Kosha (Perusahaan Film Jawa) yang dikepalai oleh Oya Soichi (Kurasawa, 1993: 238).

Dengan tujuan propaganda, pemutaran film diusahakan untuk menggapai sebanyak mungkin penonton, namun sayangnya jumlah bioskop yang tersedia hanya sedikit dan tingkat penyebarannya juga tidak merata. Mengenai rasio antara jumlah penduduk Jawa dengan bioskop pada masa pemerintahan pendudukan Jepang, Kurasawa (1993: 242-243) menulis:

Dalam hal perbandingan antara jumlah gedung bioskop dengan penduduk, jumlah gedung bioskop di Jawa sangat sedikit, yaitu jika diperkirakan jumlah penduduk Jawa sekitar 50 Juta, maka hanya tersedia sebuah gedung bioskop untuk 400.000 orang. Namun, jumlah gedung bioskop per satu juta orang sangat tidak seimbang, tergantung pada karesidenannya, dan beragam dari 0,5 di Bojonegoro sampai 8,2 di Surabaya. Secara relatif, banyak gedung bioskop di karesidenan seperti Surabaya, Besuki, Malang, dan Jakarta, sementara hanya ada 
sedikit di Bojonegoro, Cirebon, Madiun, dan Pekalongan. Dikabarkan bahwa seluruh 129 gedung bioskop berlokasi di daerah perkotaan. Menurut penelitian yang dilakukan oleh Nichi'ei pada awal tahun 1942, 52 gedung bioskop terpusat di 7 kota besar sebagai berikut: Jakarta, 13; Surabaya, 12; Semarang, 7; Bandung, 7; Malang, 6; Surakarta, 4; Yogyakarta, 3.

Mengingat sedikitnya jumlah gedung bioskop tentu saja upaya propaganda melalui media film untuk menjangkau masyarakat sebanyakbanyaknya tidak akan tercapai. Untuk itulah Pemerintah Pendudukan Jepang menyelenggarakan kegiatan pemutaran film langsung ke tengah-tengah masyarakat, kegiatan itu di kemudian hari dikenal dengan istilah "Bioskop Keliling." Kegiatan pemutaran film di luar gedung bioskop tentu saja bukan kegiatan yang baru pertama kali dilakukan sebab pada masa Hindia Belanda, Tuan Talbot dan rekan-rekannya selalu mempertunjukkan film di dalam bangunan berdinding bambu (bilik) beratap seng, yang didirikan di lapangan terbuka dan selalu berpindahpindah (Jauhari, 1992: 5). Selain itu juga, banyak perusahaan swasta di dalam rangka mempromosikan produknya, mereka menggunakan media film dengan cara memutar film dokumenter secara berkeliling di lapangan terbuka. Namun demikian, penggunaan media film sebagai alat propaganda politik secara besarbesaran memang baru pertama kali di lakukan pada masa pendudukan Jepang. Jepang telah mempunyai pengalaman yang cukup di bidang bioskop keliling ini sehingga menyelenggarakan bioskop keliling di Indonesia tidak menghadapi kesulitan. Upaya bioskop keliling mulai dilaksanakan pada bulan Agustus tahun 1942 dan berkembang lebih luas setelah pembentukan Jawa Enhai . Kantor pusat Enhai mengirim 48 operator film dan berbagai perlengkapan yang dibutuhkan di dalam upaya kegiatan bioskop keliling di wilayah pendudukan Asia Tenggara, enam orang di antaranya dikirim ke Jawa. Menjelang bulan Desember 1943, Jawa Enhai telah membentuk lima pangkalan operasional bioskop keliling yaitu di Jakarta, Semarang, Surabaya, Yogyakarta, dan Malang. Selain itu dibentuk juga 15 tim pemutar film. Beberapa pangkalan dioperasikan oleh staf Indonesia. Mereka berkeliling dari satu desa ke desa lainnya, dengan membawa proyektor film, generator, dan film (35 mm) di atas sebuah truk. Masing-masing tim terdiri atas seorang anggota staf Jawa Enhai (biasanya seorang operator), seorang pegawai Sendebu setempat, seorang penerjemah, dan seorang sopir truk (Kurasawa, 1993: 243).

Kegiatan bioskop keliling yang berusaha untuk menjangkau seluruh desa yang terdapat di Pulau Jawa tentu saja tidak mungkin dilakukan mengingat begitu banyaknya jumlah desa yang ada. Oleh sebab itu, bioskop keliling biasanya diputar di ibu kota kecamatan dengan penonton dari berbagai desa yang terdapat di kecamatan itu, mengenai hal ini Kurasawa (1993: 244) menulis:

Karena tidak mungkin mengunjungi seluruh desa dengan jumlah dan sarana yang sangat terbatas, satu atau dua desa dipilih dari sebuah son (kecamatan) sebagai lokasi pemutaran, dan rakyat dari desa-desa tetangga diundang untuk menonton. Film diputar di sebuah lapangan terbuka di dekat balai desa, dan siapa pun boleh menonton secara gratis. Pengumuman disampaikan kepada seluruh penduduk desa tetangga melalui pejabat desa dan ketua tonarigumi.

Mengingat jarak yang berjauhan antara desa dengan desa, kegiatan 
pemutaran film merupakan sebuah perjalanan safari yang memerlukan waktu yang cukup lama sebagai mana yang ditulis oleh Kurasawa (1993: 244) berikut ini:

Biasanya perlu waktu beberapa hari untuk menyelesaikan sebuah perjalanan keliling, dan dalam kasus sebuah kampanye besar dengan tujuan tertentu, sebuah tim harus melakukan perjalanan selama beberapa minggu. Misalnya, sebuah perjalanan keliling untuk kampanye peningkatan produksi yang dilakukan oleh Unit Operasi Yogyakarta bersama dengan Jawa Ehai berlangsung selama dua minggu, dari tanggal 14 sampai 30 Desember 1943, dan meliputi empat karesidenan.

Peredaran bioskop keliling ini diketahui menyebar melalui operasionalisasi dari enam kota, yakni, dari Jakarta ke Bogor dan Banten. Dari Bandung ke Priangan, Cirebon, dan Banyumas. Dari Yogyakarta menyebar hingga Solo, Madiun, dan Kedu. Sedangkan dari Surabaya ke Bojonegoro dan Madiun. Lalu dari Malang ke Kediri dan Besuki (Jauhari, 1992: 42). Di setiap lokasi pertunjukan, senantiasa diupayakan untuk menjaring sebanyak mungkin orang. Misalnya, pada acara Ulang Tahun Perang Asia Timur Raya pada bulan Desember 1943 diselenggarakan pertunjukan film keliling yang berhasil menjaring jumlah penonton yang sangat besar, dengan rincian: di Kotamadya Khusus Jakarta, 53.000 penonton; di delapan tempat di Karesidenan Jakarta, 104.000 penonton; dan di delapan tempat di Karesidenan Bogor dengan jumlah 96.000 penonton (Kurasawa, 1993: 244).

Selain menjangkau penonton dari kalangan umum, bioskop keliling juga ditujukan untuk kalangan khusus seperti kelompok-kelompok romusha, buruh pabrik, dan anak-anak sekolah. Untuk kalangan khusus ini, pemutaran film keliling dari tanggal 16 sampai 30 Desember 1943 di tiga belas tempat di Karesidenan Banten telah menjangkau sebanyak 126.000 penonton dari kalangan romusha. Adapun pemutaran film di Jakarta untuk periode yang sama menjangkau 3000 penonton dari kalangan romusha (Kurasawa, 1991: 245).

Begitulah, bioskop keliling yang dipraktikan oleh Pemerintah Pendudukan Jepang dalam hal tertentu telah memberikan sumbangan yang cukup berarti bagi kehidupan masyarakat. Jauhari (1992: 42) mengatakan:

Dalam menggarap propaganda bioskop keliling ini Jepang tidak tanggung-tanggung dalam eksekusinya. Mereka mendatangkan enam orang ahli bioskop keliling ini dari negerinya. Operasi dilakukan dengan pimpinan seorang Jepang yang dilakukan dengan menggunakan truk-truk yang hilir mudik masuk keluar kampung, menyajikan film-film gratis tersebut. Film-film yang disuguhi Jepang sebagai alat propagandanya dalam konteks luas berhasil memberikan pengaruh yang signifikan terhadap kehidupan bermasyarakat kita dewasa ini. Dampak dari pertunjukan keliling ini sangat besar bagi rakyat jelata yang dapat dicontohkan dari film mengenai praktik gotong royong dalam mengangkut air untuk memadamkan kebakaran, secara beranting, segera dijadikan cara praktis untuk mengerjakan sesuatu bersama-sama. Sementara film tentang Tonari Gumi, melahirkan organisasi warga yang sampai sekarang menjadi organisasi Rukun Tetangga (RT) dan Rukun Warga (RW). Bagi masyarakat Indonesia umumnya saat itu, film perang Jepang memantapkan keyakinan mereka bahwa kekuatan angkatan perang Jepang sangat hebat dan tidak 
terkalahkan, yang sebagai akibatnya menyebabkan banyak orang Indonesia yang tidak percaya ketika Jepang kalah perang pada Agustus 1945.

Setelah kepergian Jepang dari Indonesia, praktik bioskop keliling atau layar tancap ini mulai kehilangan kekuatannya sebab tidak ada lagi pengusaha yang mau bersusah payah keluar masuk kampung untuk mengadakan pertunjukan. Hal ini disebabkan dalam periode 1950-an sampai 1960-an bioskop menjadi sebuah bentuk usaha yang menguntungkan dan menjanjikan sehingga fokus untuk membawa film ke daerah pedesaan bukan sebuah prioritas pada saat itu.

Namun dalam perkembangan berikutnya, memasuki periode akhir 1960an dan awal 1970-an mulai tercetus keinginan untuk memutar film ke daerah yang belum terjamah oleh bioskop. Bertitik tolak dari kenyataan bahwa pertumbuhan bioskop hanya terkonsentrasi di kota besar membuat sebagian produser dan pengusaha bioskop untuk menayangkan film secara keliling ke berbagai desa yang belum memiliki kaset, video kaset' atau listrik. Hal lain yang mendorong para pengusaha film untuk mengadakan bioskop keliling ialah munculnya teknologi kaset video, laser disc maupun video VHS yang mulai digemari dan menggantikan bioskop sebagai fasilitas untuk mendapatkan hiburan tontonan film sehingga menyebabkan merosotnya pengunjung bioskop. Dapat dikatakan, hilangnya penonton dari gedung bioskop membuat beberapa produser mulai mencari penonton dengan mengadakan acara bioskop keliling walaupun dengan keuntungan yang tidak seberapa. (Jauhari: 1992: 106-108).

Begitulah keadaan perfilman nasional, mengomentari kondisi itu Jauhari (1992: 123) menulis:

Layar Tancap tidak lahir begitu saja di tengah-tengah kehidupan masyarakat urban, awalnya Layar Tancap lahir dari permasalahan yang sama seperti banyak yang terjadi dalam sejarah pembangunan negeri ini. Tidak adanya bioskop yang tumbuh di daerah selain di kota-kota besar menjadi sebab utama mengapa Layar Tancap sempat menjadi salah satu alternatif hiburan pada tahun 1970-an sampai awal 1980an bagi banyak orang di pelosok daerah Indonesia yang bahkan hingga sampai saat ini belum terjamah bioskop besar yang memutar film-film bermutu. Sesuai dengan latar belakang ekonomis dalam pendirian bioskop, bagi masyarakat pedesaan hiburan film jauh dari jangkauan mereka atau baru sekadar cerita burung dari warga desa yang mempunyai pengalaman hidup di kota.

Pada masa 1970-an, bioskop keliling berupa layar tancap sesuai dengan namanya hanya berupa pancang-pancang bambu yang ditancapkan di tanah dengan layar yang membentang di tengahnya,. Layar tancap juga dikenal oleh masyarakat luas dengan istilah Misbar (gerimis bubar) karena jika pertunjukan diganggu gerimis atau hujan pengunjung langsung bubar.

Pertunjukan layar tancap umumnya berlangsung dari jam 8 malam sampai jam 3 malam. Jika pengunjung ramai dan cuaca baik diadakan primetime hingga jam 12 malam, istimewanya karena setelah itu yang diputar adalah film-film semi erotis. Bagaimana kegiatan Layar Tancap ini berlangsung dijelaskan dengan baik oleh Dimas Jayasrana \& Ardi Yunanto yang dalam artikelnya mengatakan:

Layar tancap, dengan sendirinya tidak hanya menjadi acara yang mandiri. Film-film yang tampil tanpa jeda, tidak selalu membuat pengunjung tak melakukan 
aktifitas lain. Beberapa anak kecil tampak bermain, pemuda-pemudi yang saling menggoda, beberapa pasangan berpacaran, ramai kaki lima, atau bahkan orang-orang yang berjudi. Judi Koplok dan judi Rolet adalah yang paling populer menyemarakkan setiap pertunjukan layar tancap.

Cikal bakal bioskop keliling ini dimulai di beberapa daerah seperti NTT, yang lama kelamaan menjadi sebuah tradisi dan menyebar ke daerah lain sehingga tumbuh menjadi satu ajang bisnis yang potensial. Hal ini terjadi karena pada tahun 1970-an bisnis film terutama di daerah sedang mengalami masalah yang diakibatkan oleh lemahnya dan mahalnya jaringan distribusi film nasional saat itu. Di Bali, banyak bioskop yang terpaksa memutar film-film lama karena suplai film dari Surabaya tersendat. Para penonton setia di Bali juga menjadi berkurang karena mereka tidak mempunyai pilihan film-film terbaru. Dari permasalahan ini para pengusaha bioskop tampaknya mendapatkan cara lain mendapatkan untung walaupun hanya mempunyai koleksi film-film lama dengan menyebarkannya ke daerah-daerah pelosok yang tidak peduli atau tidak tahu film-film yang diputar adalah film-film lama yang tidak laku di kota besar ( Jauhari, 1992: 122).

Biasanya para pengusaha bioskop keliling ini menggunakan peralatan yang cukup sederhana, hanya sebuah proyektor film $16 \mathrm{~mm}$, diesel listrik dan sejumlah kru melanglang buana dari desa ke desa memberikan hiburan canggih dan murah. Dengan membayar HTM (Harga Tarif Menonton) Rp 200 - Rp 300, masyarakat pedesaan telah dapat menikmati hiburan segar yang sebelumnya hanya sekadar kabar burung mapun mimpi belaka. Keuntungan dari pengusaha ini adalah mereka tidak perlu repot mendirikan gedung karena pemutarannya bisa dilakukan di mana saja mulai dari lapangan bola, gedung SD ataupun rumah warga yang sedang mengadakan acara pernikahan ataupun khitanan ( Jauhari, 1992: 123)

Prime Time layar tancap berlangsung sampai jam 12 malam, yang biasa diputar adalah film-film semi-erotis, atau film-film sortie (film sampah); berupa potongan-potongan berbagai film yang dirangkai menjadi satu.

Layar tancap selalu menjadi fenomena, ketika elemen-elemen di dalamnya mampu melepaskan diri dan menciptakan aktifitas baru. Mendukung atau tidaknya aktifitas tersebut, tidak begitu menjadi masalah selama mampu menjaring interaksi pengunjung. Sebagian orang yang datang memang tidak selalu ingin menonton film, tapi juga menonton penonton yang lain, atau sekadar meluangkan waktu menikmati acara yang berhasil menciptakan ragam aktifitas ini. Maka sangat wajar jika mereka dapat begitu apresiatif memprotes kualitas film. Terkadang dengan melempar layar dengan berbagai macam benda, bahkan sampai memotong tiang penyangga layar dan merubuhkannya.

Secara keseluruhan, layar tancap adalah tentang bagaimana pengunjung terpuaskan. Pembicaraan tentang layar tancap yang berhasil bisa sampai satu minggu setelahnya. Modal pemilik hajatan berupa 'Proyektor Besar' $35 \mathrm{~mm}$, serta banyaknya pedagang kaki lima yang berjualan di sana, adalah salah satu cara mengukur keberhasilan acara.

Namun demikian, layar tancap, yang dulu melebihi popularitas Lenong dan Tanjidor kini mulai digantikan oleh Orkes Dangdut dan Campur Sari. Bagi mereka yang mengalami masa jayanya layar tancap merupakan pengalaman tersendiri, layar tancap adalah perkawinan yang serasi antara modernitas dan budaya lokal, antara layar terproyeksi seluloid dengan ragam aktifitas yang terjadi di dalamnya (Jayasrana \& Ardi Yunanto, 2010).

Layar tancap memang lebih banyak dikenal sebagai satu pertunjukan 
film yang terjadi di alam terbuka seperti lapangan sepakbola dengan penonton masyarakat kecil di kota besar atau masyarakat pedesaan yang sulit mendapatkan hiburan karena alasan geografis. Namun layar tancap juga mempunyai berbagai bentuk yang berbeda meskipun tetap menggunakan prinsip yang sama yaitu sebagai pertunjukan film keliling yang tidak terikat pada tempat pertunjukan (bisa di dalam atau di luar ruangan). Beberapa bentuk lain dari layar tancap itu adalah bioskop Drive-In, dan pertunjukan special screening.

Sebelum boomingnya bisnis bioskop keliling atau layar tancap pada dekade 1970-an, muncul sebuah inovasi baru yang mengambil contoh dari bioskop keliling namun memberikan nuansa urban di dalamnya. Pada bulan Juli 1970 dibukalah sebuah bioskop Drive-In, sebuah bioskop tempat penonton bisa menikmati pertunjukan film tanpa perlu turun dari dalam mobil di daerah Ancol.

Bioskop Drive-In ini merupakan satu-satunya bioskop bermobil di Indonesia dan dapat menampung 850 mobil yang membuatnya sebagai bioskop Drive-In terbesar di Asia Tenggara dan Australia, mengalahkan Sydney yang mempunyai Drive-In "hanya" berkapasitas 700 mobil saja. Harga karcis masuk bioskop ini pada saat itu adalah Rp 500 untuk orang dewasa dan Rp 300 untuk anak-anak dihitung per orang bukan per mobil. Keunggulan lainnya adalah penonton bisa memesan makanan dengan tetap duduk di dalam mobil sehingga tidak perlu repot-repot keluar. (Doenia Film. Edisi Tanggal 14 Juli 1970).

Walaupun bioskop ini pada zamannya mendapat sambutan yang meriah namun kesan yang ditinggalkan tidak terlalu baik karena bioskop Drive-In ini dikenal sebagai tempat perbuatan asusila, sehingga kemudian ditutup.

Pada praktiknya, bisnis bioskop keliling menimbulkan pro dan kontra sebagai akibat perbedaan gaya hidup tradisional dan modern yang terdapat dalam satu pertunjukan layar tancap. Sebagai contoh, di Sumatera Utara, masyarakat Kabupaten Pematang Siantar dan beberapa daerah perkebunan lainnya sempat membawa masalah ini ke DPRD Tk. I Sumut. Bahkan di Jakarta sendiri muncul permasalahan yang memaksa Acub Zainal, Gubernur Jakarta saat itu, untuk datang ke DPR dan mengikuti acara dengar pendapat. Permasalahan yang dibicarakan adalah masalah bioskop keliling yang dinilai membahayakan moral masyarakat terutama generasi muda, sebuah problema yang terdengar tidak asing lagi.

Bioskop keliling dianggap membahayakan moral generasi muda disebabkan pemutaran film tidak lagi memerhatikan batasan usia, sehingga filmfilm yang diperuntukkan bagi kalangan usia 17 tahun ke atas dapat dengan mudah dinikmati oleh anak-anak di bawah usia tersebut. Selain itu, pertunjukan film yang baru berakhir menjelang waktu subuh (dalam semalam film yang diputar bisa mencapai 3 judul film), dianggap sebagai penyebab menurunnya gairah kerja bagi para petani ataupun buruh perkebunan, bahkan para pelajar. Selain dampak negatif terhadap penonton, ternyata para pengusaha bioskop keliling ini juga demi memperoleh keuntungan melakukan pelanggaran dengan memutar film impor ataupun film nasional yang belum boleh diputar untuk bioskop keliling karena masa edarnya belum selesai untuk bioskop atau belum berusia dua tahun (Jauhari, 1992: 124)

Namun para pengusaha bioskop keliling ini mendapat dukungan dari Acub Zainal yang berbicara di forum DPR yang mengatakan bahwa bioskop keliling cukup penting, karena tidak saja memberikan hiburan segar, penerangan dan pendidikan tetapi juga memberikan dorongan dalam usaha mengembangkan film nasional. Ia juga mengatakan dalam berbagai wawancara bahwa karena usaha bioskop keliling inilah film nasional semakin merakyat, sebab bisa dinikmati oleh para petani ataupun pekerja perkebunan yang 
tidak bisa datang ke bioskop di kota besar. Dengan merakyatnya film nasional ini maka apresiasi tumbuh sedemikian rupa, menambah lapangan pekerjaan, baik yang digunakan sebagai kru atau para pedagang yang berjualan di saat berlangsungnya pertunjukan (Jauhari, 1992 : 124).

Untuk terus menjaga agar bisnis bioskop keliling menjadi bisnis yang sehat, menguntungkan dan berdampak positif bagi perfilman nasional Perbiki senantiasa berusaha mengontrol anggotanya (anggotanya berjumlah 4000 pengusaha) agar selalu mengikuti aturan main dan tidak menyalahgunakan kesempatan yang diberikan.

Namun karena banyaknya pelanggaran dan kondisi negatif dari bioskop keliling ini, memaksa Departemen Penerangan mengeluarkan sebuah Surat Edaran No. 10/Se/DPF-III/1986 tentang Pembinaan Pertunjukan Film Keliling yang bagi Perbiki merupakan sebuah ancaman karena selain mengganggu otoritas Perbiki juga merugikan bagi para pengusaha bioskop keliling. Peraturan yang dianggap mengganggu saat itu adalah ditetapkannya format film yang boleh diputar hanya berukuran $16 \mathrm{~mm}$ dan hanya boleh disaksikan oleh penonton dengan umur lebih dari 13 tahun (Jauhari, 1992 : 125).

Hal ini menjadi permasalahan sebab anak-anak berusia kurang dari 12 tahun adalah salah satu kalangan potensial untuk bioskop keliling yang jika mereka datang kemungkinan besar ditemani oleh kedua orang tuanya sehingga menambah penonton yang datang. Permasalahan mengenai format film $16 \mathrm{~mm}$ menjadi lebih besar karena film dengan format 16 $\mathrm{mm}$ sulit didapatkan perizinannya. Selain itu, pengusaha bioskop keliling dihadapkan pada kenyataan bahwa Kuasa Pemilik Film (KPF) di daerah juga melakukan aksi pemutaran film keliling dengan format film $35 \mathrm{~mm}$. Seharusnya, langkah itu harus diawasi ketat dan mereka menjadi anggota Perbiki pula, dengan memenuhi berbagai peraturan lain yang didapat setelah menjadi anggota (Jauhari, 1992 : 125).
Selain banyaknya masalah yang menghadang, Perbiki tercoreng juga namanya karena banyak pengusaha film keliling memutar film asing dan nasional yang berbau seks dan sadisme karena mengikuti kecenderungan yang terjadi di bioskop konvensional dan mengikuti kemauan pasar yang akhirnya terlanjur menyukai jenis film seperti itu. Kecenderungan ini menjadi semakin menjadi-jadi sehingga sering meresahkan masyarakat sehingga harapan Perbiki menjadi ujung tombak apresiasi film nasional sering kali tidak sesuai dengan harapan.

Namun demikian, Perbiki tetap mempunyai sisi positif yang sampai saat ini dibawa oleh pertunjukan layar tancap di manapun, baik di daerah maupun di tengah-tengah kota urban seperti Jakarta yang terlihat dari semangat idealiasme pengusahanya yang masih tumbuh subur.

Dengan kata lain, usaha ini tidak selalu bermotifkan keuntungan tetapi sering pula menjadi hobi memberikan hiburan murah kepada masyarakat. Perbiki juga terlihat menempatkan diri sebagai pengusaha kecil yang dekat dengan masyarakat kecil yang haus hiburan, informasi sehingga film menjadi sarana sebagai pendidikan informal bagi masyarakat (Jauhari, 1992: 126).

Perkembangan yang cukup menarik dewasa ini ialah adanya upaya pemutaran film keliling yang dilakukan oleh komunitas-komunitas tertentu baik di daerah perkotaan maupun di pedesaan yang tidak berorientasi komersial. Di Kroya dan Cilongok Banyumas, Komunitas Arisan Film Forum (AFF) sering mengadakan kegiatan layar tancap untuk menghibur warga sekitar. Bahkan pada bulan September 2007 komunitas ini menggelar pertunjukan layar tancap untuk menghibur para PSK di Baturaden (http://www.filmalternatif.org/?m=news.de tail\&id=36 diakses pada tanggal 10 Maret 2010, pukul 18.48).

Kemudian ada juga komunitas film Cinema Lover Community (CLC) dari 
Purbalingga yang sering menggelar pertunjukan layar tancap di desa-desa, seperti di Desa Gandasuli, Desa Karangtalun, dan Desa Penaruban pada acara 17 Agustusan atau acara lainnya (http://www.filmalternatif.org/?m=news.de tail\&id=28 diakses pada 10 Maret 2010 pukul 18.52).

Bentuk lain dari bioskop keliling yang banyak dikenal sebagai special screening ini adalah bentuk promosi sebuah film yang belum diputar di bioskop atau tidak dapat diputar di bioskop karena konten di dalam filmnya tidak memenuhi aturan yang berlaku. Sebagai contoh, film Betina besutan Lola Amaria dan dibintangi oleh Kinaryosih tersebut tidak diputar dalam bioskop konvensional namun hanya diputar dari kampus ke kampus seperti FIB UI, ITB ( http://www.itb.ac.id/news/1302 diakses pada tanggal 10 Maret 2010, Pada Pukul 18.27) dan ITS ( http://www.its. ac.id/ berita.php?nomer $=3181$ diakses pada tanggal 10 Maret 2010, Pada Pukul 18.27) Selain itu film Laskar Pelangi yang disutradarai oleh Riri Riza sempat menjelajahi kota-kota besar Australia sebagai bagian dari promosi film tersebut kepada para pelajar Indonesia yang menuntut ilmu di Australia (http://laskarpelangithemovie.blogspot.co m/2009/03/laskar-pelangi-akan-ditayangkan-di.html).

Contoh yang terlihat dari Betina dan Laskar Pelangi menunjukkan bahwa pertunjukan layar tancap tidak hanya berarti sebuah pertunjukan film bagi rakyat kecil namun juga bisa menjadi sebuah ajang promosi dan ajang pertunjukan filmfilm tertentu bagi kalangan tertentu. Walaupun tentunya layar tancap sinonim dengan pertunjukan film alam terbuka yang melibatkan masyarakat kecil dengan bambu dan layar besar sebagai mediumnya, namun perlu diingat bahwa sesuai dengan prinsipnya yang berpindahpindah dan tidak terikat pada tempat itulah bahwa konsep layar tancap mempunyai bentuk lain yang lebih luas dan berbeda dengan layar tancap yang umumnya dikenal.

Bagi sebagian masyarakat urban yang dikatakan sudah mempunyai kebudayaan film sendiri, layar tancap sudah berubah menjadi sebuah fenomena yang nostalgik dan menyenangkan yang bisa disamakan dengan kamera digital dan kamera Polaroid. Hal ini dibuktikan dengan banyaknya pertunjukan layar tancap dengan skala besar yang mengundang semua lapisan masyarakat untuk datang dengan tujuan mengingat kembali kebudayaan rakyat yang sudah hampir punah (http://www.budpar. go.id/page.php?ic=512\&id=1476 diakses pada tanggal 10 Maret 2010, Pada Pukul 19.01).

Dengan masih banyaknya kegiatan pertunjukan layar tancap di daerah-daerah yang jauh dari kota besar memperlihatkan bahwa meskipun masyarakat urban pada umumnya sudah mempunyai apa yang disebut kebudayaan film, tetapi sebagian besar masyarakat Indonesia masih menjadikan menonton film sebagai sebuah hiburan semata tanpa memperdulikan film apa yang ia tonton.

Disebut hampir punah mungkin saja benar bagi masyarakat urban yang sudah mempunyai kebudayaan filmnya sendiri, tetapi bagi penikmat dan berbagai komunitas film di daerah, layar tancap masih dapat berdiri sebagai ujung tombak hiburan rakyat yang modern dimana kebahagiaan menyaksikan sebuah keajaiban gambar bergerak untuk pertama kalinya bersama teman-teman sepermainan sambil menikmati es cendol di antara orang dewasa yang bermain kartu dan bercumbu sudah lebih dari cukup.

\section{Dari PERBIKI ke PERFIKI}

Sejak tahun 1950-an usaha bioskop keliling mulai terasa menguntungkan dan berkembang dari tahun ke tahun. Ada kecenderungan bagi orang-orang desa yang mempunyai hajatan mendapatkan "gengsi tersendiri" bila dapat menanggap film dalam acara hajatannya 
tersebut. Seiring dengan bertambahnya animo masyarakat maka usaha di bidang bioskop keliling menjadi ramai. Banyak pengusaha film yang turun ke daerah untuk memenuhi permintaan masyarakat. Dalam usaha memenuhi animo masyarakat itulah ternyata ditemui banyak kendala mulai dari kondisi ekonomi masyarakat desa, musim panen atau bukan, ada hari-hari tertentu yang harus dihindari, masalah keamanan, masalah permodalan, dan tentu saja masalah persaingan usaha sesama pengusaha film.

Oleh karena para pengusaha film bioskop keliling itu tidak berorganisasi, berbagai kendala itu harus mereka atasi sendiri-sendiri. Berangkat dari kenyataan tersebut, H. Zein Arsyad melontarkan gagasan perlunya dibentuk sebuah organisasi dengan tujuan untuk memperoleh tambahan permodalan (kredit) untuk mengembangkan usaha bioskop keliling. Tergerak oleh gagasan itu pada tahun 1977, berkumpulan 20 pengusaha bioskop keliling di rumah Suryo Kencono, di bilangan Tebet, Jakarta Selatan. Namun dalam pertemuan itu belum berhasil melahirkan organisasi. Pertemuan selanjutnya lebih banyak diadakan di rumah Ayong Suteja, di Jalan Mesjid, Cipete, Jakarta Selatan. Setelah beberapa kali pertemuan dibentuklah sebuah Yayasan Persatuan Bioskop Keliling Indonesia dengan Akte Notaris M.R. Makahanap No. 15 tanggal 23 Februari 1978 yang kemudian dikukuhkan dan disahkan oleh Pengadilan Negeri Jakarta Pusat dengan No. 70 tanggal 6 Maret 1978 (Zainal, et al. 1993: 35).

Yayasan itu diketuai oleh Suryo Kencono, akan tetapi karena kesibukannya akhirnya ia mengundurkan diri sebagai ketua dan mengakibatkan yayasan itu mengalami kevakuman. Setelah diadakan musyawarah akhirnya terpilihlah Yung Indrajaya sebagai ketua. Sebagai ketua, Yung Indrajaya melakukan reorganisasi. Ia memberi nama Persatuan Bioskop Keliling Indonesia (PERBIKI) pada organisasinya dan membentuk kepengurusan di mana ia sebagai Ketua Umum; lalu Boih Sumardi sebagai Ketua I; selanjutnya A. Aidizars sebagai Sekjen; dan Ayong Suteja serta Munthalibsyah sebagai bendahara. Reorganisasi yang dilakukan bertujuan agar PERBIKI dapat diakui secara hukum dan agar kedudukannya dapat disejajarkan dengan induk organisasi perfilman lainnya, seperti PPFI, GASFI, GPBSI, KFT, dan PARFI. Program Kerja PERBIKI ialah (1) Membenahi organisasi, (2) Menertibkan pelanggaran-pelanggaran yang sering terjadi di lapangan, dan (3) Memasukkan film ke desa-desa (Zainal, et.al. 1993: 36).

Di dalam rangka membenahi organisasi, PERBIKI melakukan penertiban terhadap anggota-anggotanya. PERBIKI mengharuskan anggotaanggotanya untuk mengurus rekomendasi dari organisasi. Setelah memiliki rekomendasi barulah anggota yang bersangkutan dapat mengurus izin pemutaran film di suatu daerah. Namun demikian, kenyataan di lapangan sulit sekali untuk menertibkan pengusaha bioskop keliling yang bukan anggota PERBIKI.

Di lapangan pemutaran film yang berbau pornografi seringkali terjadi sehingga film membentuk citra negatif di masyarakat desa. Memang muncul kesan seolah-olah bioskop keliling membuat malas orang desa, mabuk-mabukan, judi, dan menyebabkan kriminalitas. Untuk itu lah pada bulan Agustus tahun 1980, Yung Indrajaya bersama pengurus DPP Perbiki lainnya menghadap Pangdam V Jaya untuk meminta bantuan menertibkan para pengusaha bioskop keliling yang liar tersebut. Kemudian di dalam melaksanakan program film masuk desa, PERBIKI bekerjasama dengan GPBSI dan PT Perfin menjadikan wilayah Jawa Barat sebagai pilot proyek. Program ini menyebabkan pertumbuhan usaha bioskop keliling menjamur. Selain menguntungkan para pengusaha film, program ini juga membantu pemerintah di dalam mensosialisasikan program-program pembangunan (Zainal, et al. 1993: 36). 
Selanjutnya, untuk memperbaiki roda organisasi, pada Maret 1982 DPP PERBIKI melalui rapat pleno melengkapi kepengurusannya dengan membentuk Dewan Harian dengan susunan: Ketua, Hasan Basri Raja Medan; Sekretaris, Hidayat Effendi; Anggota, Tadjuddin, Boih Sumardi BA dan Zein. Dewan Harian ini bertugas menyusun program kerja dan pelaksana harian dalam mengembangkan organisasi. Kepengurusan ini (Periode 1978-1983) bisa disebut sebagai periode gerak juang yang berusaha membentuk Jati Diri PERBIKI sebagai organisasi yang tidak semata usaha di bidang ekonomi tetapi juga dibidang sosial (Zainal, et al. 1993: 38). Menutup masa kepengurusan periode 1978-1983, diadakan Kongres PERBIKI yang pertama. Setelah melalui dinamika kongres, maka terbentuklah susunan kepengurusan baru yaitu: Ketua Umum, Acub Zainal; Ketua Umum I, Hasan Basri; Ketua Umum II, Munthalibsyah; Ketua Bidang Organisasi, Hasan Basri Raja Medan; Ketua Bidang Pembinaan, Sumislan AD; Ketua Bidang Operasi, Riyanto; Sekjen, Hidayat Effendi; Wk. Sekjen, Boih Sumardi; Bendahara, H. Somad; Wk. Bendahara, Ayong Suteja (Zainal, et al. 1993: 38).

Kepengurusan periode 1983-1988 ini memiliki program kerja internal yang meliputi: melaksanakan semua keputusan kongres, menyempurnakan kepengurusan DPP dan Cabang di seluruh Indonesia, tertib organisasi, tertib anggota, tertib operasional, program penyuluhan dan pendidikan bagi anggota, serta membentuk koperasi bagi anggota PERBIKI. Adapun program kerja eksternal ialah: menciptakan hubungan yang harmonis dengan organisasi film lainnya, menciptakan tata operasional yang serasi dan selaras dengan kepentingan perfilman pada umumnya dan peraturan-peraturan serta kepentingan GPBSI selaku induk organisasi dan PT. Perfin sebagai pelaksana SK 3 Menteri di dalam menata peredaran film nasional, membantu pemerintah dalam melaksanakan TAP MPR No.
11/MPR/1983 mengenai GBHN khususnya di bidang penerangan dan mass media.

Selama kepengurusannya, pengurus periode 1983-1988 berhasil mencapai target kerja internal sebesar $80 \%$ hanya program pendidikan anggota dan pembentukan koperasi yang tidak tercapai. Untuk sasaran eksternal, capaian PERBIKI di antaranya: melaksanakan pemutaran film-film yang diproduksi oleh Deppen dan departemen-departemen lainnya dalam setiap kegiatan pemutaran film; turut menyukseskan Pemilu 1977; tidak pernah tertinggal dalam kegiatan FFI, dan berhasil menghibur masyarakat yang berada di daerah pinggiran (Zainal, et al. 1993: 39).

Pada tanggal 4 dan 5 November 1988 diadakan Kongres II yang berhasil membentuk kepengurusan periode 19881993, yaitu: Ketua Umum, Acub Zainal; Wk. Ketua Umum, Ibrahim Sinik; Ketua Hubungan antara Instansi/Lembaga, A. Munthalibsyah; Ketua Bidang Organisasi/operasional, Soeharyono; Ketua Bidang Litbang, Pujiasmanto; Sekretaris Umum, Hidayat Effendi; Wk. Sekretaris Umum, Ibnu R. Sawarno; Bendahara Umum, Ayong Suteja; Wk. Bendahara Umum, H. Somad.

Pada periode ini program kerja yang utama adalah: menyukseskan Pemilu 1992, menumbuhkan movie going habit masyarakat, mempertahakan eksistensi film nasional, membantu program ABRI masuk desa lewat pemutaran film, membentuk koperasi anggota, melakukan penggalangan massa untuk mendukung pembangunan nasional.

Pada periode ini terjadi peristiwa bersejarah yaitu diubahnya PERBIKI menjadi PERFIKI (Persatuan Perusahaan Pertunjukan Film Keliling Indonesia) yang diputuskan melalui Musyawarah Kerja yang diadakan pada tanggal 2 Oktober 1991. Susunan kepengurusan pun berubah menjadi: Ketua Umum, H. Acub Zainal; Ketua Hubungan antar Instansi/Lembaga, A. Muthalibsyah; Sekretaris Umum, Ibnu R. Sawarno; Wk. Sekretaris Umum, H. Boih Sumardhi B.A; Ketua Bendahara 
Umum, Ayong Suteja; Wk. Bendahara Umum, Ari Suryo Wibowo; Organisasi dan Operasional, Soeharyono.

Adapun tujuan dari PERFIKI adalah: (1) ikut serta mencerdaskan bangsa, (2) membantu pemerintah dengan menyebarluaskan informasi pembangunan melalui pertunjukan film, (3) ikut serta mengembangkan perfilman nasional dengan cara mempertunjukkan film-film Indonesia secara berkeliling ke pedesaan di wilayah Republik Indonesia, menggalakkan pertunjukan film untuk mendorong terciptanya iklim agar film Indonesia memperoleh tempat yang layak di negeri sendiri, (5) membantu pemerintah agar film sebagai media massa berfungsi sebagai alat pendidikan, penerangan, dan hiburan, (6) mengupayakan tumbuhnya komunitas dagang agar terdapat keseragaman pemasaran demi kemajuan antarperusahaan pertunjukan film keliling dengan para produser film atau kuasanya (Zainal, et al. 1993: 40).

\section{PEN UTU P}

Film masuk ke Indonesia dalam bentuk yang paling awal dalam format yang sederhana berupa pemutaran film dalam bangunan berdinding bambu, beratap seng di lapangan terbuka dan selalu berpindah-pindah. Format yang demikian itu di kemudian hari diberi label sebagai bioskop keliling atau misbar (gerimis bubar). Eksistensi bioskop keliling semula disebabkan oleh jumlah gedung bioskop yang teramat sedikit dan tidak merata keberadaannya serta harga tiket yang tidak semua rakyat dapat menjangkaunya. Realitas itulah yang ditangkap oleh para pengusaha film untuk secara proaktif mendatangi penonton dengan bioskop kelilingnya.

Dalam perkembangan berikutnya eksistensi bioskop keliling lebih dikukuhkan oleh motif politik yang menjadikan film sebagai instrumen politik. Pemerintah Pendudukan Jepang menyelenggarakan bioskop keliling secara massif sebagai media propaganda untuk kepentingan perangnya. Banyak film dokumenter dibuat untuk menanamkan ideologi Jepang ke dalam benak orang Indonesia agar bangsa Indonesia mendukung Jepang dalam upaya memenangkan Perang Asia Timur Raya. Sebagaimana Pemerintah Pendudukan Jepang, Pemerintah Orde Baru juga menggunakan bioskop keliling sebagai media propaganda program pembangunan yang dicanangkan Orde Baru. Keharusan untuk memutar film-film dokumenter produksi pemerintah dalam setiap pemutaran film di bioskop keliling, dan menggalang massa untuk kampanye Golkar dalam setiap Pemilu merupakan ritual yang wajib dilaksanakan. Adapun di masa reformasi, bioskop keliling lebih dimanfaatkan oleh berbagai komunitas untuk mengisi kegiatannya. Dalam alam reformasi memang tumbuh berbagai komunitas yang menyadari bahwa film bukanlah semata-mata media hiburan tetapi karya budaya yang bisa dimanfaatkan dalam berbagai bidang kehidupan.

Terlepas dari kepentingan politik, secara de facto, bioskop keliling telah memberikan kontribusi positif terhadap perkembangan film nasional. Bioskop keliling menjadi ujung tombak peredaran film-film Indonesia sampai ke pelosokpelosok desa. Rakyat terhibur dan secara tidak langsunng juga memahami apa dan bagaimana budaya Indonesia itu. Bukankah sebuah film mencerminkan budaya yang dimiliki oleh masyarakat si pembuat film.

\section{DAFTAR PUSTAKA}

\section{Buku}

Ardan, S.M. 1984.

Data Perbioskopan di Indonesia. Jakarta: Direktorat Pembinaan Film dan Rekaman Video, Gabungan Pengusaha Bioskop Seluruh Indonesia dan PERFIN. 
Biran, Misbach Yusa. 2009.

Sejarah Film 1900-1950: Bikin Film di Jawa. Jakarta: Komunitas Bambu dan Dewan Kesenian Jakarta.

Erwantoro, Heru. 1994.

Sejarah Perfilman Indonesia Masa Kemerdekaan 1945-1994. Bandung: Departemen Kebudayaan, Direktorat Jenderal Kebudayaan, Balai Kajian Sejarah dan Nilai Tradisional Bandung.

Irawanto, Budi, Novi Kurnia, dan Rahayu. 2004.

Menguak Peta Perfilman Indonesia. Jakarta: Kementerian Kebudayaan dan Pariwisata RI bekerjasama dengan Jurusan Ilmu Komunikasi FISIPOL UGM dan Fakultas Film dan Televisi IKJ.

Jauhari, Haris (ed.). 1992.

Layar Perak: 90 Tahun Bioskop di Indonesia. Jakarta: Gramedia Pustaka Utama.

Junaedi, Nanang. 1994.

Bisnis Film di Indonesia: Studi Deskriptif tentang Proses Komunikasi Film dalam Konteks Dominasi Film Amerika di Indonesia. Skripsi Jurusan Ilmu Komunikasi Universitas Gadjah Mada. Yogyakarta: UGM

Kurasawa, Aiko. 1993.

Mobilisasi dan Kontrol. Alih bahasa oleh Hermawan Sulistyo. Jakarta: Gramedia.

Pane, Armijn. 1953.

"Produksi Film Tjerita di Indonesia". Indonesia. Th. IV. No. 1/2. Januari/Februari, hal 53.

Zainal et al. (Dewan Redaksi). 1993.

Mengenal Bioskop Keliling Lebih Jauh. Jakarta: DPP PERFIKI.

\section{Surat Kabar/M ajalah}

Doenia Film, edisi Djuli 1970.

Madjalah Ilmu dan Budaya. Th. IX. No.6. Maret 1987. Hal. 461.

Republika, 30 Maret 1994.

\section{Internet}

$\mathrm{h} t t p: / / w w w$.filmalternatif.org/? $m=$ article.detail $\& i d=18$.

Dimas Jayasrana \& Ardi Yunanto, Layar Tancep; Proyeksi sebuah Pesta. Diakses pada tanggal 10 Maret 2010, pada pukul 19.16.

http://www.filmalternatif.org/?m=news.detail\& $i d=36$.

Diakses pada tanggal 10 Maret 2010, pukul 18.48.

http://www.filmalternatif.org/?m=news.detail\& $i d=28$

Diakses pada tanggal 10 Maret 2010, pukul 18.52.

http://www.itb.ac.id/news/1302. Diakses pada tanggal 10 Maret 2010, pukul 18.27.

http://www.its.ac.id/berita.php?nomer=3181. Diakses pada tanggal 10 Maret 2010, pukul 1827.

http://laskarpelangithemovie.blogspot.com/200 9/03/askar-pelangi-akan-ditayangkandi.html.

http://www.budpar.go.id/page.php?ic=512\&id $=1476$.

Diakses pada tanggal 10 Maret 2010, pada pukul 19.01. 